\title{
Is It Capitalism?
}

\section{Marshall W. Meyer}

University of Pennsylvania, USA

ABSTRACT I introduce the three articles in the MOR Editor's Forum on Chinese Capitalism. I then ask whether China's recent economic growth has been driven by a vibrant capitalism or instead has become an end in itself, supported by government policies promoting high rates of fixed asset investment. There are two key observations. First, gross domestic product (GDP), measured and reported at four levels of government, has much greater salience than corporate profits, often undisclosed. Second, fixed asset investment accounted for more than 60 percent of China's 2009 GDP and nearly two-thirds of 2008-2009 GDP growth, levels unprecedented for a major economy. Rather than capitalism, I argue that institutionalized GDP growth today accounts for China's rapid economic development.

KEYworDs capitalism, China, economic growth, gross domestic product (GDP)

\section{INTRODUGTION}

国进民退 Guo Jin, Min Tui (State advances, people retreat)

This Editor's Forum on Chinese Capitalism includes three papers by pre-eminent scholars, Andrew G. Walder, Neil Fligstein with co-author Jianjun Zhang, and Nan Lin. All explore the contours of the contemporary Chinese economic and managerial systems although through somewhat different lenses. And all are extraordinarily articulate. However, the arguments made by these authors vary in familiarity and, by implication, the likely comfort of readers. I'll introduce the papers in order of familiarity - in my judgment. I'll then move to even less familiar territory by asking whether China departs so far from the precepts of Western capitalism that it is something else entirely even if we don't fully grasp what it is. I'll take the further step of arguing that it is critical to frame the Chinese economic system as capitalist or something else, more likely the latter than the former, to anticipate how Western and Chinese economies will interact going forward. It is not clear that this interaction will be altogether amicable. The Western business 
community wants a China congenial to capitalism in order to extend its reach further into China. The Obama administration is debating whether engagement or confrontation is most likely to yield a congenial China. Both business and the administration may be engaged in wishful thinking because China and Western capitalists may discover that they have so little in common that congeniality becomes difficult. Thus, it is important to understand China for what it is rather than what we wish it to be and hence to question the assumption that China will inevitably and inexorably move toward a familiar form of capitalism. It is important to continue the scholarly conversation and extend it beyond the academy because the stakes are so great. A capitalistic China will be a formidable global economic force but still viewed as a competitor, a rival, not a predator. A China operating outside the framework of capitalism may be viewed less amicably, especially if Western economies remain weak and debt-ridden while Chinese economic growth continues unabated.

\section{THE THREE ARTICLES}

The most familiar of the three articles is Andrew G. Walder's (2011). Walder begins with a sketch of the shift from state to private ownership in China. The surface facts speak for themselves: from 1998 to 2003, the proportion of value added produced by state-controlled enterprises fell from 55 to 41 percent. At the same time, the contribution to value added by privately controlled firms rose from 28 to 52 percent. (A residual category is collectively controlled firms.) This trend notwithstanding, Walder notes, China's largest firms remain statecontrolled or state-owned. Walder then sketches three key research questions to be applied in each of four sectors of the economy. The questions include mapping the change in state ownership and control over newly restructured and privatized enterprises, mapping changes in networks linking owners of these enterprises, and mapping changes in patterns of movement across boundaries of these organizations - the presumption is that as state influence declines, movement from enterprises to government and back to enterprises will diminish. The four sectors of interest to Walder encompass the state-owned sector, the privatized or restructured state sector, the transactional sector (i.e., private firms transacting principally with government), and the entrepreneurial sector. Which of these sectors grows and with what managerial networks will determine whether China evolves a highly statist form of capitalism or a form of capitalism more familiar to the West.

Like Walder, Fligstein and Zhang (2011) have an agenda for research, but it is on the contours of Chinese economic development rather than the development of Chinese managerial elites. The agenda also moves away from the familiar because it involves puzzle solving and pattern recognition rather than hypothesis testing. Fligstein and Zhang begin by trying to pigeonhole existing 
theories of Chinese economic development. Ultimately they find the exercise unsatisfying because eight categories are needed to classify these theories, none especially attractive:

... the factors which are supposed to have led to Chinese economic growth are also held to have made that growth less than it could be, or the factors that had driven economic growth at one time period become barriers later on ... this reflects the limits of empirical study and the lack of systematic, overarching theoretical thinking about what is happening. (Fligstein \& Zhang, 2011: 41)

Fligstein and Zhang's first approximation to overarching theoretical thinking is in fact meta-theory: ' . . . every transition to capitalism has produced a new variety of capitalism, and in each transition, a set of common problems have had to be resolved' (Fligstein \& Zhang, 2011: 47). This is thesis, antithesis, and synthesis. At every fork in the road yet another fork lies ahead. A second approximation involves comparing China's national development trajectory with the trajectories of other countries, yet even this proves challenging. Among the many forms of state-driven organized or illiberal capitalism, according to Fligstein and Zhang, French dirigisme may prove most instructive for China. But even this comparison seems forced as the authors admit: France is a multi-party democracy, China is not. France has independent (very independent) trade unions, China does not. And so forth. In the end, in my judgment, Fligstein and Zhang pose a very telling paradox. On the one hand, they believe that a deeper understanding of Chinese economic development lies in the comparative capitalism literature. On the other hand, they cannot find a satisfactory comparison - the differences between China and other systems of capitalism are that great. It may be that Chinese capitalism is unique, sui generis in the way it forges 'a new way to produce economic growth' (Fligstein \& Zhang, 2011: 59). On the other hand, it is possible that China is not capitalistic, at least as capitalism is ordinarily conceived.

Finally, I turn to Nan Lin's (2011) paper, which is the least familiar of the three. There are actually two parts to the paper, current and prospective. The current portion reviews the literature on state capitalism and then enunciates the concept of centrally managed capitalism (CMC) where the state plays an active role as a capitalist as in China. Lin claims that the essential features of capitalism are present under $\mathrm{CMC}$ including calculating capitalists, a free market, and wage labour. The difference between CMC and Western capitalism lies mainly in governance: whereas under Western capitalism boards of directors are largely independent of the state, under CMC the ultimate board of directors is the state. The difference in governance means that there will be much greater coordination across firms and sectors under CMC than Western capitalism, that selection and advancement of key personnel will be far more centralized, and that national champions are more likely to be designated by the government than winners of rough-and-tumble 
competition. Lin acknowledges limits to centralization in the Chinese context given the power of local governments (especially Shanghai and Guangdong) but argues, unlike most scholars, that these 'fuzzy relationships' maintain flexibility for the 'political-top and market-bottom' (Lin, 2011: 80) corporate form characteristic of CMC.

The prospective portion of Lin's paper concerns the ideological justification for CMC. The present choices are stark, according to Lin, Western capitalism, a mature stage of socialism, or an indigenous enlightened authoritarianism, the first not viable given the pre-eminent role of the Chinese Communist Party. Mature socialism is sometimes conflated with but is not identical to a construct called Xiaokang where moderate prosperity exists alongside stability provided by the government. Xiaokang does not exclude self-interest but does preserve overarching authority. Importantly, according to Lin, unlike Marxism Xiaokang is an indigenous ideology with deep historical roots in China. Further, according to Lin, Xiaokang may already have crept into the official rhetoric of China and is manifested in CMC, which combines self-interest and authority. Beyond Xiaokang, however, Lin hopes for Datong. Datong moves from overarching authority to generalized norms of trust and reciprocity. Moreover, following Lin (2011: 87), 'it is a system clearly based on democracy in order to achieve harmony'. As Lin notes, calls for democratization have so far met stiff resistance in China. Still, he is hopeful of a 'slow but firm infusion of democratic elements ... at every level' (Lin, 2011: 63) of China.

\section{ARE WE ASKING THE RIGHT QUESTION?}

Now to my own thinking, which differs somewhat from the three papers in the forum. The concern is that the three papers ask how rapidly and in what respects China is moving toward capitalism. The better question, I believe, is whether China is moving toward capitalism or away from it, and if the latter then is China on a collision course with Western capitalism? My answer, suggested by the subtitle, is that China's current trajectory is not in the direction of capitalism - I emphasize the current trajectory, not China's overall trajectory since reform and opening in 1978. Rather, the current trajectory is toward central management. A further suggestion is that having co-opted Western capitalism and mirrored many of its surface features, China today poses an unprecedented and profound challenge to Western capitalism that scholars and policymakers have only begun to grasp.

Let's begin with the definition of capitalism. All three articles, I believe, could benefit from defining the key attributes of capitalism. Generally, capitalism is a form of economic activity dominated by private firms. Private firms compete in markets for goods and services and in markets for capital. At the end of the day, a key test of a capitalistic enterprise is earnings (profits). Earnings serve several 
purposes. A portion of earnings is retained by the firm and invested in the furtherance of the business. In the classic form of capitalism described by Max Weber (1958) virtually all earnings are retained and reinvested. A portion of earnings is paid as dividends and interest to encourage shareholders and bondholders to continue investing in the firm (and pointedly in the case of bondholders, to meet the firm's legal obligations). Current and future earnings may also be shared with employees in the form of bonuses, stock options, grants of restricted stock, and the like to motivate their continued contributions to the firm. Individual investors look to current and future earnings to gauge the value of their holdings; absent earnings or prospective earnings, investors will pull out. Strong earnings, then, drive a virtuous cycle: since earnings are reinvested in the firm, attract investors, and motivate employees to perform, firms with strong earnings will grow. Moreover, strong prospective earnings drive a similar virtuous cycle by attracting investment and motivating employees as their shares and options increase in value.

Ideally, under capitalism the role of the state is limited. The state sets the rules, limits excesses (e.g., monopoly power), and intervenes in markets as a last resort. Although the state may operate infrastructure enterprises like postal systems, railways, and utilities, state-owned and private enterprises rarely compete because the latter are hopelessly disadvantaged given the vast resources available to the state. This said, state participation in capitalistic economies is often greater than the ideal, even in the U.S. Witness the government takeover of Fannie Mae (Federal National Mortgage Association) and Freddie Mac (Federal Home Loan Mortgage Corporation), historically private but government-sponsored enterprises, which were placed under the conservatorship of the Federal Housing Finance Agency in September, 2008. Witness also the incursions of the federal government into the financial and automotive sectors, most temporary, under TARP (Troubled Assets Relief Program) as the recession deepened. To be sure, an expanded role of the state is acknowledged in the literature on late industrialization and the developmental state (e.g., Amsden, 1991) where government subsidization of private enterprise, as distinct from government ownership, when tied to appropriate incentives can produce a virtuous cycle of growth as South Korea and Taiwan have experienced. Moreover, the possibility, indeed the reality, of a vibrant capitalism in the context of coordinated market economies is acknowledged in the current varieties-of-capitalismliterature (Hall \& Soskice, 2001). In this literature, ‘... firms are the central actors in the economy whose behaviour aggregates into national economic performance ...' (Hall \& Gingerich, 2009: 452), firms are largely profit seeking but profit seeking is moderated to the extent firms rely on strategic rather than market coordination, and strategic coordination, as distinct from market coordination, operates mainly through non-governmental institutions (e.g., boards of directors, labor unions) rather than direct government ownership and control. 
The last point bears repeating: coordination operates through independent institutions rather than government.

On the surface, it appears that China is moving rapidly toward dominance by private firms and hence capitalism as I have defined it. For example, the non-state sector today accounts for roughly 70 percent of industrial output and a slightly smaller percentage of industrial value added. However, the picture of private-firm dominance is less clear if one compares the domestic private sector with the state sector, omitting foreign-invested enterprises. In 2008, the gross output of Chinese private industrial enterprises was 13.6 trillion RMB compared to 14.4 trillion RMB for the state-owned and state-controlled sector. In 2007, the latest date for which these statistics are currently reported, the value added of private industrial enterprises was 2.6 trillion RMB compared to 4.0 trillion RMB for the stateowned and state-controlled sector (China Statistical Yearbook, 2009: tables 13-8 and 13-12). If past trends continue, the overall output of privately owned industrial firms will shortly surpass the state sector, and their value added will surpass the state sector in 3-5 years. However, continuation of past trends is not guaranteed. According to World Bank (2010) estimates, massive assets were infused into stateowned enterprises as part of economic stimulus measures implemented in late 2008 and 2009. The result was asset growth of SOEs at rates in excess of the Chinese private sector. If these assets are used efficiently, then the sales and value added of the state sector will be reinvigorated; if not, then an asset-bloated state sector will become an even greater drag on the economy than it now is. Neither scenario in my judgment comports with an image of a vibrant Chinese capitalism, even a CMC.

In China, firms face earnings pressure if only to help fill the coffers of the central government. For example, SASAC (State-owned Assets Supervision and Administration Commission) has stepped up its campaign to increase dividend payouts by firms under its purview but with only modest success so far. From 2007 to 2009, these dividends accounted for less than 1 percent of central government revenues (Wall Street Journal, 2010). However, intentionally or otherwise, there are pressures in the opposite direction as well. SASAC together with the bank regulator CBRC (China Banking Regulatory Commission) and the securities regulator CSRC (China Securities Regulatory Commission) have sharply limited stock options for senior managers (Caijing, 2008). Regardless, the pressure to produce earnings is not nearly as intense in the West if only because earnings can be very hard for the public to see. Among other anomalies, the earnings of China's largest firms are rarely reported publicly and in a timely manner. Unlisted firms, of course, have no obligation to disclose earnings and rarely do. Listed firms, or better, listed entities do disclose earnings, but most listed entities are subsidiaries rather than parent group corporations whose revenues and Fortune Global 500 rankings are displayed in Walder's Table 2. Take, for example, the Baosteel Group, number 307 on the 2008 Fortune Global 500. Baosteel's single listed subsidiary in 2008 was the 
Baoshan Iron and Steel Co., Ltd, the latter accounting for about half the revenues but almost all the profits of the parent Baosteel Group. To be sure, the parent group reports its full financial results to both the State-owned Assets Supervision and Administration Commission and the State Administration of Taxation. However, since the state is the sole shareholder of the Baosteel Group, as distinct from the listed Baoshan Iron and Steel, there is no obligation to disclose Baosteel's results publicly. (Baosteel issued an unaudited 2007 report showing group sales, earnings, and assets, but I cannot find later reports. Similarly, China First Auto Works issued an unaudited 2008 report of sales, earnings, and assets, but I cannot find a 2009 report.) A few large group corporations interested in overseas acquisitions, like Sinochem, which hoped to acquire the Canadian fertilizer giant Potash, voluntarily release audited group-level financial statements, and some smaller enterprises where the full assets of the group rather than one or more subsidiaries are listed, for example China International Marine Container, also release consolidated statements. Still, reliable information about the earnings performance of unlisted entities, which retain a large portion of the assets of the largest Chinese firms, remains scarce.

Rather than earnings, what you see in China is gross domestic product (GDP) [or its local counterpart, gross regional product (GRP)]. Chinese GDP (or GRP) statistics are ubiquitous and published for four levels of the Chinese administrative system: national, provincial, municipal or prefectural, and county. GDP growth remains the most critical success measure for local officials; another critical success measure is jobs. The Chinese press pays almost as much attention to GDP statistics as government officials, although sometimes with a jaundiced eye. Semi-annual reports of regional economic statistics elicit headlines like 'Regional GDP growth outpaces nation's economy' (the story continued, 'Something is fishy in the provinces ...'), but the distortions are endemic and accepted as a fact of life (China.org.cn, 2010). The contrast with the U.S. could not be greater. The Bureau of Economic Statistics of the U.S. Department of Commerce releases annual, not semi-annual, GDP statistics by state and metropolitan area, but these numbers garner little if any attention in the press, perhaps because recent GDP numbers have been so tepid but more likely, in my judgment, because few people care.

When you trace the trajectory of recent Chinese GDP, its significance becomes even clearer. Figure 1 shows the growth of China's GDP from 1990 to 2009. What is remarkable is that the global economic tsunami barely dented China's growth from 2008 to 2009, and GDP growth has returned to near double digits in 2010. Two facets of the Chinese economy have been especially critical to its overall growth. One is foreign trade. China has been unusually dependent on foreign trade compared to other countries. Thus, it is surprising that China's GDP growth accelerated beginning in 2006 despite the sharp contraction of foreign trade relative to GDP from 2006 to 2009. China's trade ratio, the standard measure of dependence on foreign trade (imports plus exports expressed as a percentage of 
Figure 1. China's gross domestic product (RMB billions) by year

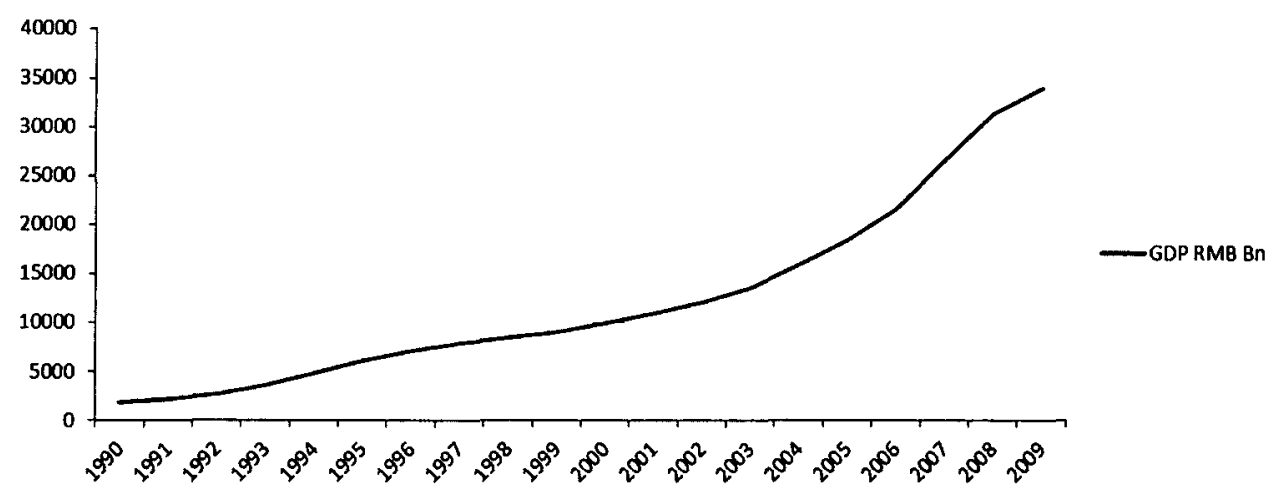

Source: CEIC database.

Figure 2. China's trade ratio [(imports + exports)/GDP] by year

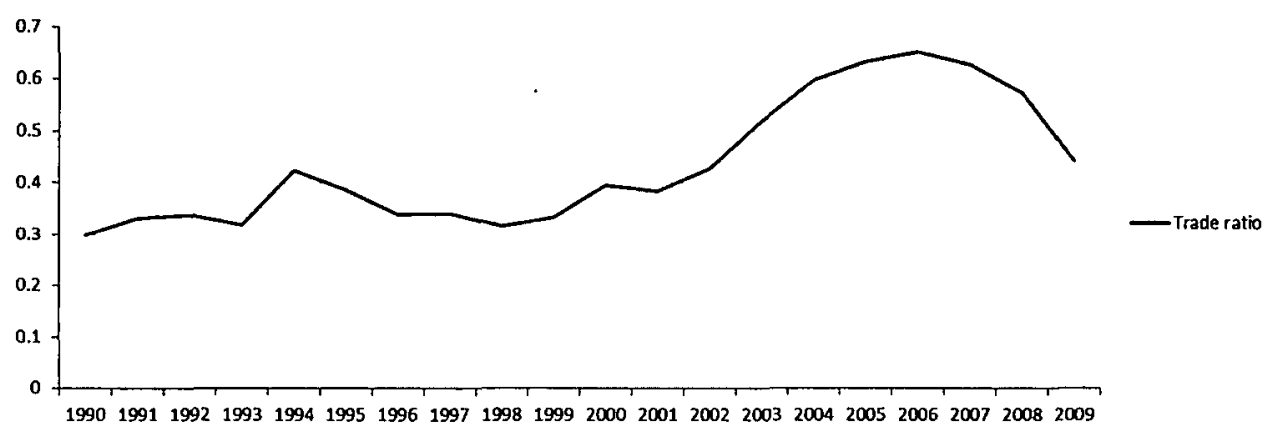

Source: CEIC database.

GDP), dropped by nearly a third from 2006 to 2009 , from 65 to 44 percent, as shown in Figure 2.

Another facet of the Chinese economy critical to overall growth is fixed asset investment, investment in plant, equipment, infrastructure, and most significantly real estate. From 2006 to 2009, China's fixed asset investment leapt from 51 to 62 percent of GDP as shown in Figure 3. Indeed, the 2008-2009 increase in fixed asset investment, from 55 to 62 percent of GDP, was equivalent to two-thirds of China's 2008-2009 GDP growth. According to People's Daily Online (2010), capital formation accounted for 92 percent of Chinese GDP growth from 2008 to 2009. As best as I can determine, household consumption has lagged Chinese GDP growth until recently. Household consumption data for 2009 comparable with the GDP, foreign trade, and fixed asset investment statistics I have discussed are not yet available since the CEIC series on household consumption ends in 2007. However, according to the Chinese National Bureau of Statistics, from 1990 to 2006 household consumption dropped from 48 to 36 percent of Chinese GDP and slipped 
Figure 3. China's fixed asset investment/GDP by year

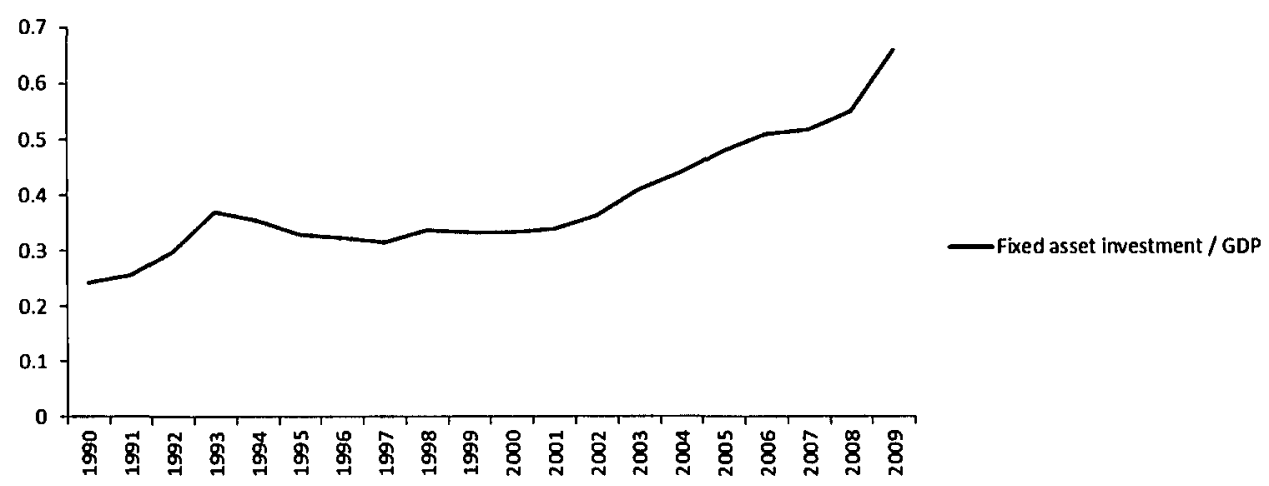

Source: CEIC database.

another two percentage points, to 34 percent of GDP, in 2008 (China Statistical Yearbook, 2009: tables 2-17 and 2-18).

To summarize what we have learned so far: first, GDP and GDP growth appear to be far more significant for China than for Western countries; second, Chinese GDP growth was driven by foreign trade and fixed asset investment through 2006 or perhaps 2007 and has been driven almost entirely by fixed asset investment since; and third, the proportionate contribution of household consumption to growth appears to have declined over time in sharp contrast to Western countries, especially the U.S., where household consumption increased steadily as a percentage of GDP until the economy went into recession in 2008.

Critical to an appraisal of the state of capitalism in China is the source of fixed asset investment driving recent GDP growth. Government policy appears to be the main driver of accelerated fixed asset investment. Beginning in the fourth quarter of 2008, the Chinese central government took several steps to stimulate the economy. Most visible was an RMB 4 trillion centrally funded economic stimulus package directed mainly toward physical infrastructure projects. Of the RMB 4 trillion, two-thirds or approximately RMB 2.7 trillion was earmarked for expenditure by local governments. However, planned local government stimulus spending was much greater, nearly RMB 10 trillion, almost four times the central government contribution. Borrowing - largely from the state-owned commercial banks - helped local governments bridge the gap, and these funds, in turn, were invested into infrastructure projects built by state-owned construction companies using materials purchased from state-owned concrete and steel companies. Other state-owned enterprises borrowed directly from the state-owned commercial banks to invest in the Chinese real estate market. This practice continued until last March when SASAC ordered the companies under their purview to shed their real estate operations - whether SASAC companies have divested or hidden their real estate investments cannot be determined. Local government and SOE borrowing, mainly 
for infrastructure improvement and real estate investment, caused bank lending to skyrocket in 2009. In 2008, Chinese commercial banks extended a total of RMB 4.2 trillion in new loans, but new lending more than doubled to 9.6 trillion RMB in 2009. The central government has set an RMB 7.5 trillion cap on new loans for 2010 , but it is all but certain that the cap will be exceeded by a substantial margin since 2010 commercial loans totalled RMB 6.9 trillion at the end of October (Chinadaily.com, 2010a).

The evidence, then, suggests that GDP growth is not merely a mantra but has become deeply institutionalized in China. Government at all levels set GDP targets, the financial resources of government and the banking system, still government-controlled, are mobilized in support of these targets and funnelled through state-owned firms, and, critically, career advancement for government officials depends on attaining GDP targets ( $\mathrm{Li} \& \mathrm{Zhou}, 2005)$. The institutionalization of GDP growth persists despite the distortions it creates. Today the principal distortions are a burgeoning money supply, estimated to have grown by as much as 54 percent in the last 2 years (Bloomberg, 2010), rampant inflation, and, prospectively, strict credit and price controls. To be sure, there are good reasons for the prominence of GDP, most importantly its connection to employment and, as a consequence, to use Premier Wen Jiabao's phrase, social harmony. And entrepreneurial opportunities abound in an environment where GDP growth takes precedence - these opportunities are especially abundant in the interior of China where rapid urbanization is anticipated. Still, capitalism differs profoundly from institutionalized GDP growth. Capitalism is driven by firms, GDP growth by government. Capitalism seeks profits; institutionalized GDP growth production, employment, and, ultimately, social harmony.

\section{THE GDP MACHINE VERSUS WESTERN GAPITALISM}

Until this point, Western capitalism and institutionalized GDP growth in China have coexisted comfortably. As China opened to foreign investment beginning in 1980, Western firms rushed in, initially to manufacture for export, later to build their brands and penetrate the Chinese market. Among other advantages, China offered inexpensive migratory labour and favourable tax policies for foreigninvested firms. China also devalued its currency gradually from 1985 to 1993 and then by 30 percent from 1993 to 1994 (China Statistical Yearbook, 2009: table 17-2), the latter to reverse a sharp economic downturn. The combination of inexpensive labour, favourable tax policies, and cheap currency attracted badly needed foreign investment and technology to China. Importantly, each dollar invested in China was a double-duty dollar, contributing to both China's GDP through fixed asset investment and Chinese foreign reserves through the sterilization mechanism making it unnecessary to sell the dollars in international currency markets. 
The comfortable coexistence of Western capitalism and institutionalized GDP growth began fraying well before 2008 and has frayed rapidly since. The RMB has risen almost 20 percent against the dollar since 2004, wage rates for migratory workers rose rapidly beginning in 2006, and foreign-invested firms lost their favourable earned income tax treatment beginning in 2008. Worse, the economic tsunami beginning in the fourth quarter of 2008 nearly caused international trade and hence Chinese exports to seize up. To keep the GDP engine running the Chinese government intervened dramatically in the economy. The initial intervention was a massive stimulus package, resulting in over-investment in infrastructure and industrial plant; subsequent interventions aimed to sop up excess capacity by subsidizing domestic sales of consumer durables, especially in the countryside of China, as well as exports. The stimulus and subsidy programmes have in turn ballooned China's money supply, triggering inflation in real estate and more recently in foodstuffs (Chinadaily.com, 2010b). The spectre of uncontrolled inflation today requires further government intervention in the form of higher interest rates and higher reserve requirements, and selective price controls are under active consideration. Together, this series of interventions has brought the Chinese economy increasingly under the control of the government. China is more centrally managed today than it was 5 or 10 years ago. But I contend that it is not CMC.

The last, however, is not my main point. The main point is that we have observed a highly resilient, or what appears to be a highly resilient, Chinese economy, where its resilience is gauged by GDP growth. China reports high single- or even double-digit GDP growth while the U.S. and EU economies founder. More remarkably, rapid GDP growth has continued despite China's dependence on low-cost manufacturing for export to the U.S. and EU. An explanation is required, and it is found in capitalism, albeit a CMC where the state acts as an entrepreneur writ large. I am arguing that state capitalism has had little or nothing to do with correlation between an increasingly centralized Chinese economy and its rapid growth. To the contrary, I believe that GDP growth in China is an imperative, a given that is deeply institutionalized and will be maintained at almost any cost. And I believe that China has had to centralize control of the economy in order to maintain acceptable rates of GDP growth given the parlous state of the global economy. In other words, rather than causality running from centralization (i.e., CMC or a variant of it) to growth, the actual causal direction is the reverse, from the growth imperative to centralization. And I think this argument can be tested rigorously, although there is not space to perform the tests adequately here.

It is extremely important to test my argument that the growth imperative drives centralization of the Chinese economy in juxtaposition with the CMC argument or the more general claim that China's current resilience is due to its movement toward capitalism. The post-World War II track record of centrally managed or command economies is not good as illustrated by the experience of 
the former Soviet Union. If we extrapolate from recent experience, then relying on a command economy to pull the world out of the deepest recession since the Great Depression may yield a nasty surprise. On the other hand, the Keynesian revolution coupled with the experience of the U.S. from 1932 to 1945, that is, from the Great Depression through World War II, suggests that central coordination of the economy may be critical at times of economic distress. The intersection of the facts - whether China is moving toward capitalism or a centrally controlled economy - and their framing - whether pre- or post-World II experience is judged most relevant - will determine how Western capitalism will interact with China going forward. If China continues to march toward capitalism, even a CMC, and the post-World War II experience remains relevant, then all may be relatively well. If, however, China reverts to a command economy, albeit a GDP-driven command economy rather than a Soviet-style centrally planned economy, then the possible outcomes, from the perspective of Western capitalism, are less pleasant. On the one hand, should China falter, as all command economies have since World War II, then so will the global economy and we may face a second round of the Great Recession. On the other hand, should China remain resilient while the West continues to falter because it ignores the lessons from the Great Depression and World War II, then Chinese influence will extend and Western capitalism may then have reached an asymptote, in which case capitalism as we know it could face a crisis of the sort anticipated by Marx and Engels (1948) a century and a half ago. It is natural to hope for the outcome best fitting our theories and that China will move toward capitalism even if it is not Western capitalism. But as social scientists we must deal with the facts, and the facts, in my judgment, do not compel the conclusion that China is today becoming increasingly capitalistic.

A final set of facts: a colleague - an anonymous reviewer of this introduction - suggested that the central government's intervention into the Chinese economy should be understood as a transient, a response to an unprecedented financial crisis that will reverse once the drag of excessive fixed asset investment on government budgets and productivity becomes manifest. Would this were so. However, predictions that abnormally high levels of fixed asset investment will self-correct are not new. Six years ago when Chinese fixed asset investment approached the then unprecedented level of 45 percent of GDP, a Hong Kongbased consultancy wrote:

... in the past couple of years, official data suggest China has set a new [fixed assets to GDP] record for a major economy. Indeed, this may be one of the reasons the authorities have been so keen to calm investment given that ratios in excess of the mid-thirties have often spelt trouble for other countries. However, if we assume that the recent spike beyond 40 percent is a cyclical aberration ... (DSG Asia, 2005: 1) 
China's fixed asset to GDP ratio has grown inexorably since and today exceeds 60 percent, and fixed asset investment accounts for an even larger portion of GDP growth. This compels a straightforward question: does a vibrant capitalism or institutionalized GDP growth best explain China's reliance on investment in fixed assets?

\section{GONCLUSION}

The three articles on Chinese capitalism in this forum are singly and together brilliant, requiring the attention of social scientists of all stripes as well as of policymakers. This said, all three articles created some dissonance for me because it is not clear that China is today moving in the direction of capitalism. In particular, GDP growth, supported by government policies favouring high levels of fixed asset investment, appears to take precedence over profits in China. Hence, this lengthy and perhaps irrelevant introduction.

\section{REFERENCES}

Amsden, A. 1991. Diflusion of development: The late-industrializing model and greater East Asia. American Economic Reviewe, 81(2): 282-286.

Bloomberg. 2010. China banks' yuan positions rise most in 30 months. [Cited 30 November 2010.] Available from URL: http://www.bloomberg.com/news/2010-11-27/china-october-forexreserves-rose-most-in-30-months-updatel-html

Caijing. 2008. China's execs sweating over stock options. [Cited 28 December 2010.] Available from URL: http://english.caijing.com.cn/2008_06_27/100071919.html

CEIC. 1990-2009. China premium database. [Cited 30 November 2010.] Available from: University of Pennsylvania libraries.

China Statistical Yearbook. 2009. Beijing: China National Bureau of Statistics.

China.org.cn. 2010. Regional GDP growth rate outpaces nation's economy. [Cited 30 November 2010.] Available from URL: http://www.china.org.cn/business/2010-08/02/content 20620613.htm

Chinadaily.com. 2010a. Banks come close to reaching annual lending quotas. [Cited 30 November 2010.] Available from URL: http://www.china.org.cn/business/2010_08_02/content_ 20620613.htm

Chinadaily.com. 2010b. Rising labor shortage hits key regions. [Cited 30 November 2010.] Available from URL: http://www.chinadaily.com.cn/bizchina/2010-11/29/content_11622392.htm Inflation has also sharply curtailed the supply of migratory workers, whose wages barely cover food costs in Shanghai and Guangdong.

DSG Asia. 2005. Chinese fixed investment in an historical context. [Cited 24 December 2010.] Available from URL: http://www.dsgasia.com/vip/Writings/Rap060605.pdf

Fligstein, N., \& Zhang, J. 2011. A new agenda for research on the trajectory of Chinese capitalism. Management and Organization Revieze, 7(1): 39-62.

Hall, P., \& Gingerich, D. 2009. Varieties of capitalism and institutional complementarities in the political economy: An empirical analysis. British Joumal of Political Science, 39(3): 449482.

Hall, P., \& Soskice, D. (Eds.). 2001. Varieties of capitalism: The institutional foundations of comparative advantage. New York: Oxford University Press.

Li, H., \& Zhou, L. 2005. Political turnover and economic performance: The incentive role of personnel control in China. Journal of Public Economics, 89(9-10): 1743-1762.

Lin, N. 2011. Capitalism in China: A centrally managed capitalism (CMC) and its future. Management and Organization Review, 7(1): 63-96. 
Marx, K., \& Engels, F. 1948. Manifesto of the Communist Party, S. Moore (Tr.). New York: International Publishers.

People's Daily Online. 2010. Capital formation contributes 92 percent of China's GDP growth in 2009. [Cited 30 November 2010.] Available from URL: http://english.peopledaily. com.cn/90001/90778/90862/6885729.html

Walder, A. G. 2011. From control to ownership: China's managerial revolution. Management and Organization Revieze, 7(1): 19-38.

Wall Street fournal. 2010. China seeks higher payout from state firms. [Cited 30 December 2010.] Available from URL: http://online.wsj.com/article/SB100014240527487 04543004576051581004988362.html?mod=WSJASIA_hps_LEFTTopWhatNews

Weber, M. 1958. The protestant ethic and the spirit of capitalism, T. Parsons ( $\mathrm{Tr}$.). New York: Scribner.

World Bank. 2010. Quarterly update. [Cited 30 November 2010.] Available from URL: http:// sitcresources.worldbank.org/CHINAEXTN/Resources/318949-1268688634523/ Quarterly_June_2010.pdf

Marshall W. Meyer (meyer@wharton.upenn.edu) is the Tsai Wan-Tsai Professor of Management and Sociology at the Wharton School of the University of Pennsylvania. He is the Executive Senior Editor of MOR.

Manuscript received: December 18, 2010

Final version accepted: January 5, 2011

Accepted by: Anne S. Tsui 